\title{
賀茂別雷神社修理方による営繥活動 \\ HOW DID SYURIKATA BUILD AND REPAIR BUILDINGS AT KAMOWAKEIKAZUCHI SHRINE
}

\author{
中西大輔* \\ Daisuke NAKANISHI
}

\begin{abstract}
This paper reports how Construction Organization built or repaired buildings at Kamowakeikazuchi Shrine. "Syurikata" was known as Construction Organization at Kamowakeikazuchi Shrine. But details were unclear. It was not yet reported what process was used in building or repairing buildings at Kamowakeikazuchi Shrine.

Based on old diaries kept at Kamowakeikazuchi Shrine, Syurikata acted to build or repair buildings in the following three processes:

1. Syurikata received a request from Kamowakeikazuchi Shrine

2. Syurikata acted

3. Syurikata reported a result to Kamowakeikazuchi Shrine

These processes applied to both inspection and construction at Kamowakeikazuchi Shrine.
\end{abstract}

Keywords: Kamowakeikazuchi Shrine, Syurikata, Construction Organization, Building and

Repairs

賀茂別雷神社，修理方，造営組織，新造・修理

1. はじめに

\section{1. 研究の背景}

賀茂別雷神社には歴史的価值を評価されている多くの建築物があ る。本殿・潅殿と呼ばれる社殿は昭和 28 年、国宝に指定され、平成 6 年には世界文化遺産にも登録された。このほか昭和 28 年には境内・ 外の摂末社および舎屋が計 36 棟重要文化財に指定されている。

これらの建築物は幾度にもわたる新造・修理を経て保存されてき た。江戸時代だけをみても幕府による造営が 8 度（寛永・延宝・正 徳・寛保・安永・享和・天保・文久) 行杂和水ている。寛永度の造 営では境内にある多くの建築物が新造された。その後、本殿・権殿・ 貴布袮奥社では延宝度以降も毎回新造が行なわれ、文久度に新造さ れた社殿が現存している。一方、そのほかの社殿・舍屋では、延宝 度以降は修理が行なわれ、寛永度新造の社殿・舎屋が現存している。

それにもかかわらず、誰が賀茂別雷神社で新造・修理を行なった かといらことについては、ままり知られていない。中世以前に賀茂 別雷神社で建築工匠を務めた林家が近世に大徳寺の棟梁を務めたこ とが知られてはいる注1)。しかし、林家に伝わる木割書と現在の社殿 を比較すると異なる部分が多い。本殿の木割值は現在の本殿のもの よりも嘉元度の本殿のものにより近いことが指摘されている注2)。ま た、摂社のうち大田社、奈良社、沢田社、氏神社の実測值からは木 割書とは異なる木割システムが想定された注3)。そのため、社殿・舎
屋の技術的系譜は不明な部分が多いといえる。

この理由として史料の調查が進んでいなかったことが举げられる 賀茂別雷神社に残る史料（以下、賀茂別雷神社文書）は膨大であり、

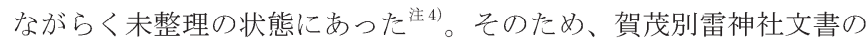
文献調查を有効に行なうことができなかったのである。

それが近年、賀茂別需神社文書の全貌が明らかとなり、史料調查 が比較的容易となった。全貌が明らかとなった過程は次のような もので女る: 平成 9 年、賀茂別雷神社文書の整理事業が開始された 平成 15 年、整理事業の成果が『賀茂別雷神社文書目録』注5) として まとめられた。そして平成 18 年、賀茂別雷神社文書はその価値を評 価され、重要文化財に指定された。

その結果、賀茂別雷神社の歴史について多くのことが明らかにな った注6)。これちけて、筆者も江戸時代 8 度の造営、社殿の木割、 建築工匠の組織について、調査を行なってきた。そして、賀茂別雷 神社の建築工匠は賀茂別雷神社の支配下に入り活動を行なっていた ことなどがわかった注7。

この結果から、賀茂別雷神社で新造・修理の意志決定を行なった ものが存在したと考えられる。最終的には賀茂別雷神社の神官たら によって評議が行なわれ新造・修理が決定したことは容易にわかる。 しかし、新造や修理を差配していた組織の実態は不明である。賀茂 別雷神社の建築工匠は賀茂別雷神社の支配下にあったからである。

\footnotetext{
* 日本学術振興会 特別研究員 PD (京都府立大学大学院 生命環境科学研究科)
}

Research Fellow, Japan Society for the Promotion of Science 
支配下にある建築工匠たちは、自由に新造や修理を行なうことを許 されていなかった。賀茂別雷神社の命を受けて新造や修理を行なっ たのである。新造や修理にあたり賀茂別雷神社の意向を仰がねばな らなかったのである。現在みる賀茂別雷神社の建築物が江戸時代ど のようにして維持されてきたか知るには、賀茂別雷神社の新造・修 理に扔ける指示系統を明らかにしなければならない。

\section{2. 賀茂別雷神社の造営組織に関する既往の研究と問題点}

これまで、賀茂別雷神社の造営に関する組織（以下、造営組織注 ${ }^{8}$ ) として、作所奉行、社頭月行事、修理方というものが知られてきた。 作所奉行については、造営に関する記事や、算用状に記される支払 先などから、

・止大工以ドの番匠を指揮すべき立場にあったらしい

・職務の中心は、作所奉行という名称からしても殿舎等の作事 にあったことは閒違いなからう

などと指摘されている注9)。社頭月行事については、天文 20 年（1551） から慶長 18 年 (1613) に算用状を作成していること、天正 18 年 (1590) の片岡社造営に要する費用を請け取っていることが明らかにされ、

・社頭月行事が社殿造営の際に一定の役割を担っていたことは 明らかである

・主たる性格は月番の社頭営繥係であったろう

との見解が述べられている注10)。修理方については、3人で構成され ていたことが示され、

・神殿以下の諸建造及び建造物の修繮を掌る

と紹介されている注11)。

しかし、作所奉行、社頭月行事、修理方がいわゆる造営組織とし て機能していたかどうかは不明のままである。社頭月行事は作事 に必要な材料や建築工匠なじに対する支払い走記録した算用状を作 成しているため、造営組織である可能性が高い。しかし、作所奉行 と社頭月奉行については |一定の役割」などともあるように職務の 全貌が明らかになってはいない。一方、修理方についても『賀茂别 雷神社由緒略記』にもとづき「修繕を掌る」とされていることから、 造営組織である可能性が高い。とくに修理方については、明治維新 直前の記録をもとにしているため、その存任が碓実な組織とみなす ことができる。しかし、上記の記述からはより詳しい職務内容を知 ることはできない。これらは勘定や由緒に特化した史料の研究から 明らかになったことであるためと考えられる。

\section{3. 研究の目的と方法}

そこで本稿では、修理方が賀茂別雷神社において建築物の新造お よび維持管理をするにあたりどのような職務を担っていたのかを当 時の文献に基づいて具体的に明らかにする。修理方の職務を建築物 の(管理と(b)新造・修理にわけてみていくことにする。修理方は賀 茂別雷神社内の組織であるため、(1)賀茂別雷神社から修理方への行 動、(2)修理方の建築物・建築工匠に対する行動、(3)修理方から賀茂 別雷神社一の行動、という3のの手順ぶ䒓えら机る。

そのために本稿では、賀茂別雷神社に伝わる賀茂別雷神社文書、 とくに『日次記』を用いる。以下、『日次記』を引用する場合はとく に断らず、必要に応じて年月日を記す。『日次記』は『賀茂別雷神社 文書目録』のなかで次のような性質が明らかにされている售 ${ }^{12)}:\lceil 氏$ 人物中の公的な日記」である。作者は、賀茂別需神社において毎年 鍵で選出される氏人（物書、執筆）である。構成は 1 年分の内谷を
1 冊にまとめることを基本としているが、時代が下るにつれ 1 年分の 内容を数冊に分けて作成されている場合も方る注13)。そして、「江戸 時代の上賀茂社の基礎史料となるものである」と評価されている。

扱う時代は元禄 5 年（1692）から享保 20 年（1735）までとする。 上限を元禄 5 年としたのは、この年用務繁多を理由に修理方が発足 したからである (9月 27 日条)。下限を享保 20 年としたのは、修理 方の職務・権限怯、発足後付け足されていき、享保年閒までをひと つのまとまりと捉えられるからである注 ${ }^{14)}$ 。さらに、修理方発足前の 組織との比較を一るるためにも、組織の発足から完成するるまでに限っ たほうが得策であると考えたからである。

なお、修理方を指寸名称は複数ある。『日次記』のなかでは「修理方」 のほかに「修理奉行 (衆)」、「修理方奉行 (衆)」なども呼ばれている。 本稿では修理方として統一寸る。

\section{2. 修理方の職務}

\section{1. 境内にある建築物の管理}

\section{a. 建築物の状況を調査するよう依頼される}

少なくとも江戸時代の賀茂別雷神社では建築物の状況を把握する ために見分が行なわれていた。毎年、境内全体の建築物を見分する 機会が設けられていた。また、建築物が破損した時には随時見分が 行なわ秃た。じちらの場合にも修理方が参加している注 15 )

全体の見分は破損の有無によらず定期的に行なわれているが、臨 时の見分に注寄合から修理方一見分が依頼される。宝永元年 (1704) の『日次記』には、

河原町源三郎家ノ事、近々修補可被加哉ノ事、依之評之上、修 理方有見分、積之上、可有披露極ル（1月22 日条） しある。このこしから、

1. 寄合で取り上げられる注 16$)$

2. 修理方に見分が命じられる主 17)

3. 修理方に建築工匠などから見積りをとるよう命じられる ${ }^{\text {湆 } 189}$

4. 寄合に新造・修理案と見積りを提出する注 19 )

といら手続きを経て新造・修理が決定されると考えられる。場合に よっては、寄合後に見分が行なわれてから修理方に要請される場合 もある(宝永 5 年 1 月 27 日条なじ)。

ただし、手続きは省略される場合もある。あらかじめ見分が行な われたときには修理方に見分の要請がされない場合もあった。例え ば宝永 5 年の修理でけ、

廿二日、神殿·舎屋破損二付、寄会已後、惣検分、則御修理之所々 被書付、執筆続之、各御相談、修理方へ可被仰渡候事(1 月 27 日条) とあり、「2. 修理方に見分が命じられる」は省略されている。また、 軽度の破損である場合や簡単な処置で済屯場合にも修理方に見分の 要請がされないことがあった。例えば享保 8 年、本殿・権殿下に動 物が入り込んだときのことである。初め、掃除講中一処理を命じたが、

当分繥候分二而者、難成候間、人工等江も被仰付、縁，下等、 御吟味候而、被縉間舖哉ノ事 (3 月 22 日条)

という知らせをうけた注 20)。これに対して賀茂別雷神社は「御修理方 へ可被附」という決定を下している。このように、「当分繥」という ような応急処置には、修理方は関わ方ないこともあるが、建築工压 などが必要な「縉」には修理方が関与していたことがわかる。

b. 新造・修理の計画を立案する 
これらの見分によって修理が必要と判断された建築物は修理方に よってリストアップされる。元禄 8 年には、修理方が社殿・舎屋の 破損状況について見分を行ない、翌日にリストが提出されている(2 月 27 日条) 注21)。さらに、破損状況が分類されることもある。享保 2 年の『日次䚶』には、前日に行なわれた全体の見分に対しての評決 がある(1月 22 日条)。そのなかに「大破・小破積り可被申付」とあ るように、破損状況を「大破」、小破」に分けて見積りを行なうよ う指示されている。修理の優先順位を決めるためである注222。

なお、リス卜には見分前に破損の報告があったもの以外が含まれ ることもある。このような事例は享保 5 年に行なわれた貴布祢での 見分報告などにみられる。享保 5 年、修理方によって正大工が貴布 袮一見分に派遣された。そして見分後に止大工から「其外御屋根二 所斗少々損候」という報告が修理方に女がっている（6月11 口条）。

次に、リストアップされた工事内容について、修理方け建築工匠 などに見積りを指示する。見積りには特定の建築工匠などに直接指 示するカ法、複数の建築工匠などに低頼する法がある。正大工に 直接指示する場合として、宝永 5 年には「御修理方奉行中承二而」 正大工に見積りが命じられることが決定している（1月 27 日条） 注23) また正徳 4 年（1714）には修理方から会所を通して議題に上がった 鍛治の選定問題について「大工（名前略）取次)鍛治、心安キ様二 被思召候間、大工と宜御相談, 上、可被仰付事」として鍛治を選ん でいる（11月 2 日条） 注24)。複数の建築工匠などに依頼する場合とし て正徳 3 年に注、

修理方衆上り東小屋) 普請、大工共へ被申付候事、重而惣大工 二可被仰付事（閏 5 月 2 日条）

といらものがある。ここでは入札と明記されていないが、5 日後の『日 次記』で「入札開，事」として結果が記されている(閏 5 月 7 日条)。 同様に、元禄 6 年に行なわれた材木小屋の屋根蕞替え丁事について は 2 人の瓦師へ見積りが依頼され、見積りの結果を修理方が寄合で 報告している (3月 23 日条) 洋25)。

\section{c. 新造・修理案を提出する}

こうして作成された社殿・舎屋に関する新造・修理の案を、修理 方が賀茂別雷神社の寄合に捉出する。捉出の状況は、

- 修理奉行中より披露、方々玉垣柱根継并井垣ノ根・燈籠木根 継等仕候由)事 (元禄 6 年 5 月 8 日条)

·今日、修理職奉行中より貴布袮社修覆窥帳被認、執筆書之（元 禄 11 年 6 月 15 日条)

などとなる。なお、リストのほかに絵図が提出されている場合がある。 例えば正徳 4 年の評議所作事では、「評議所ノ普請ノ絵図। 3 枚と門 の絵図が提出されている (2月16日条、10月12日条)。

\section{2. 境内にある建築物の新造・修理 \\ d． 新造・修理案について賀茂別雷神社から許可・指示をうける}

新造・修理の方法については寄合の意見が重視された。江戸時代 の賀茂別雷神社では寄合によって意思決定を行なっていたからであ る。『日次記』の調査から、賀茂別雷神社の意志決定を行なう寄合に は立会寄合、小寄合があることが明らかにされている注26) そそれによ れば、立会寄合は賀茂別雷神社における最高の評議機関である。こ の立会寄合は社司 21 人上、六役 6 人を含む氏人 21 人で行なわれる。 開催日㹥基本的に毎月 2 日、7 日、12 日、17 日、22 日、27 日と定め られている注27)。小奇合は立会奇合を規模・内谷ともに簡単にしたも
のである。この小寄合は神主・月奉行・六役で行なわれる。 そのため、修理方から奇合へ問い合わせが行なわれる場合がある。 元禄 6 年の『日次記』には、

新造ノ蔵ノ前二米斗場ノ庇付候へ八、言ノ外蔵习高ク拵申せ称 八成不申候間、御座敷/東/方一庇 $习$ 付、斗場二叮被成欺/事 $(8$ 月 9 日条)

とある。これに対してて賀茂別雷神社が最終決定を下している注28)。ま た宝永 6 年には、風折れの樹木（杉）を保管するため木屋に庇をつ けることが修理方から提案されている。当初、賀茂別雷神社からは 材木を保管することの夕が依頼されていた。しかし、その場所がな かったことにより、庇をつけることになったのである。そして、賀 茂別雷神社に見分を依頼している (5 月 16 日条)。このほか、新造・ 修理の仕様について複数の案が建築工匠などから提案された場合も 修理方が寄合にかけている。例えげ享保 5 年、貴布祢奥社の屋根这 299 で雨漏りがあった。そこで、修理方が正大工を貴布祢に派遣し見分 させた。その結果正大工が提案した修理法は2つあった：銅㤆で 補修をする方法と打覆いを設ける方法である(6月11日条)。これを 受けて賀茂別需神社で修理方針が決定している。宝永 7 年には、修 理のための見分が行なわれたあとに正徳度造営が決定している。こ のときは修理方から賀茂別雷神社に、

先頃被相窥候御修理, 義、先可被相止候哉、但被窥相济候間、 屋袏ナト大破ノ所可被仰付哉（3 月 28 日条）

といら問い合敄せが寄合の席で行な扒れている洋301。

また、寄合が修理方法を決定する場合もある。亨保元年、修理方 は能舞台の屋根補修を「油紙二而積り吟味被申付」というように命 じられた。見積りを捉出したところ、次のような決定が下った：

大分它義二而、其上近年之内、又損し可申、先当年者損し破レ 漏候処、啮せン゙而張り被置、様子可被相見旨、修理方中へ入 魂可有之候事 (6 月 12 日条)

新造や修理の費用も寄合の審議を通して決定していた。見積りの 額が高ければ、賀茂別雷神社によってより低額の見積りを出すよう に指示される場合も学る。元禄 6 年には、正大工から見積りを受け 取った賀茂別雷神社が、「今少下直二仕候様二奉行衆より入魂可有之」 しいう決定を下し、修理方を通して見積額の引き下げを指示してい る (8 月 15 日条) 注31)。正徳 2 年には、「道具木ヤ」を新造するにあ たり、見積り額にさしたる違いがないことから、最安值をつけた建 筑工匠の見積り額で役人工の「申合」によって行なうことが決定し ている (2 月 22 日条)。また正徳 4 年には、

修理方衆被申候八、評議所御門/ 鉄物并くら/鉄物書付、鍛治 より何返も上候間、何レ二可被成候哉/事（11月 2 日条） とあるように、修理方は見積りの結果を賀茂別雷神社に報告し、決 定をまっていることがわかる。修理方壮賀茂別雷神社と鍛冶との間 にたち、交渉を行なっていたということができる。

修理を急がなり㞦ばならないときには寄合が開かれるまで待てな いこともある。そのときは、会所に報告している例がある：

十五日晚景二御修理奉行中より会所一酒殿屋衫之義、見苦敷候 間、暫クも早ク繕可然旨届有之、然ル上者、小寄合相催し、相 談候者、今日二者出来も申間敷候間、奉行中并職中、大工・屋 衩ヤ等召連、見分之上、被縊可然、相談二而、則被申付候事 (享 保 2 年 1 月 18 日条) 
ここでは修理が遅れてしまうことを理由に、小寄合を開かず、見分 のうえ、修理を行なうことが決定している。なお引用文中の「酒殿 屋㸚之義」とは、15 日に酒殿の煙り出し近くで火事が起こったこと によるものである (1月 17 日条)。

修理方が小寄合を開く例もある。享保 4 年の『日次記』に、

御能舞台、今日之雨二漏候二付、御能両日雨降二而八如何二付、

為御相談、御修理奉行衆上り小寄会被相催候事（6月28月条） という記事がある。能舞台は 6 月晦日と 7 月 1 日に行なわれる御戸 代会神事で必要となる。次に奇合が開かれるのは 7 月 2 日頃である。 そのため、寄合をまつことができず、修理方が小寄合を開いている と考えられる。先の貴布祢奥社层根修理の場合も 2 つ修理方法の うちどちらにするか、修理方は小寄合を開き、賀茂別雷神社に決断 を仰いでいる (享保 5 年 6 月 22 口条)。

このような場合、新造・修理案を提出せずに修理に取り掛かるこ ともある。(1)単純な修理で済むとき、(2)時間がなく応急処置を行な うとさ、がそうである。(1)の例挙げると、京保 5 年の『日次記』に、

氏神井垣破損二付、月番・御修理方・六役等検分以後、小寄会、 出席、神主・月番・六役等也、会所清遠（7月9日条）

と記されている。このときは修理方のリストアップや修理案が提出 されていない。破損個所が 1つであるため、リス卜は必要ではなか ったと考えられる注 32 。また、井垣の修理け壊れた個所を直すだけの 単純なものであると思われる。そのため、修理案についても必要が なかったと若えられる洋33)。(2)の例を挙げると、享保 9 年の『日次記』に、

其通難被指置義二付、御修理奉行衆 $习$ 被招、明日早天二、正大 工被召連、様子被窥、縜可被申付、若天井も貫候八、其上二 而相談可有之旨也（12月13 日条）

と記されている。これは貴布祢の梅宫社で屋根に破損が見つかった という届けがあったてとをうけての決議である。賀茂別雷神社では 放置しておくことができず、翌朝修理方と正大工を派遣し、|繕」お せるよう命じている。天井にも破損があるようなら、さらなる刘処 が必要であるため、「繕」のうえ要相談というのが決議の内容である。

\section{e. 新造・修理を差配する}

寄合の絬果、新造・修理が決定したものについては、修理方を通 して建築工匠などに新造・修理の指令が下る注 34 。例えば享保 3 年、 棚尾社の「御鎖ノ座金物」が「抜厅」た。そして、「修理方上り餙屋 习呼二被遣、其金物 7 被調、正大工二可被仰付事」といら決定が下 つている (7月 17 日条)。このことから、棚尾社の金物修理にあたり、 飾屋と直接交渉するのは修理方であったことがわかる。なお、後半 の「正大工二可被仰付事| は寄合から指示したということか、修理 方から指示したということか不明瞭である。享保 2 年には、

先日、修理方一被仰渡候間、追付大工参り可申候、茶釜八儀八

職中より被調可被遣卜テ箱被申渡候（3月 17 日条）

とある。これは、貴布袮の詰番から貴布祢での修理を急いでくれる ようにという要請をう淑ときの裁決である。修理の要請をうけた ときには「(修理個所略) 此雨所、大工二被申付候事」と記されてい る(2月 22 日条)。そのため、建築工匠を決定するのは寄合であるか もしれないが、実際に指令を下すのは修理方によると考えられる。

作事の間、修理方は現埸の差配を行なう。差配の対象は新造・修 理両面にわたっている。以下では修理の例を多く引用しているが、 道具木屋などで新造の例もみられる（正徳 2 年 2 月 22 日条）注35)。
現場の状況をみて修理方は修理方針の決定や変更を寄合に提言す る。宝永 6 年には、

（略）詰番（名前略）被相願候筧之事、竹二而可仕旨被仰遣候一 共、(名前略) 両人見分申候処、此度木 $习$ 仕二付、当分)儀之様 二相聞へ候へ共、左様之事二而無之、只今迄八筧二テ被取候水、

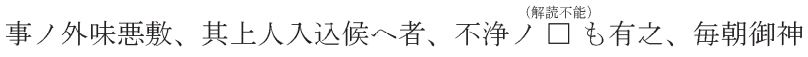
供ヨモ被備進候処、右之通気之毒、彼是以被相願候処、尤二相 見一申候、迚ノ儀二、木二テ被仰付被遣候八、可然二存候へ共、 新二式十間程拵申事二御座候故、了簡難成、帰り申候之旨也（略） (6月 8 日条)

とある。このように、貴布祢での筧修㻦にあたり、当初賀茂別需神 社の方針では新しい筧を竹で作ることになっていた。しかし、修理 方が実際に見分を行ない使用者に実情を尋衫てみると、竹よりも木 で作るほらが適していることが判明した。修理方け勝手に決めるこ とができないとして、ほかの修理が完了後、上賀茂に戻り賀茂別雷 神社の意向をうかがっている。このほか正徳 4 年には、境内に新し く建てる文庫に社殿や鳥居の古材を用いることを修理方が提案し採 用されている (9月 27 日条) 注36)。

見分によって立てられた新造・修理の期間は変更されることもあ る。享保 5 年には貴布祢での修理にあたり「一両日中も逗留可有之」 という書状が賀茂別雷神社に送られてきている（7月22日条）。修理 個所が予想以上に多かったためであるという。一方、同年に行なわ れた貴布袮の牛一社における修理は当初の予定と異なり1日で済ん

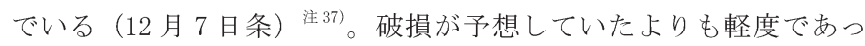
たためであるという。また、新造・修理中に新たな修理個所が見つ かる場合もあった。例えげ享保 7 年、予定していた作事がおおかた 終了し、上賀茂に戻ってきた修理方から未修理部分抢よび新たな修 理個所について報告があった。賀茂別雷神社は「御修理奉行中被申合、 重而被上、可被申付旨也」として作事の規模を拡大、期間を延長し ている(10月 27 日条)。

遠所での作事にあたり、現場と賀茂別雷神社との間で連絡が必要 なときには、現場に詰めている修理方から上賀茂に残っている修理 方に宛てて手紙で伝えられる。例えば、享保 10 年には「御修理奉行 (名 前略)、此間、御用二付、キ布祢、被居候而、相役 (名前略) 方一手 紙到来之事」として、修理に用いるための樹木伐採に関する報告が 行なわれている (6月 3 日条)。

さらに、享保 10 年の『日次記』からは御戸代会能見物所も修理方 が設置していたことがわかる：

御戸代会能見物所、近年、御修理方より被構之、社用場多候間、 向後三ヶ所二被究、床二脚ツ、敷候様二可被申付二決（6 月 22 日条)

「近年」とあることから、当時は修理方の職務の 1 つとして定着して いたことがわかる。

\section{「. 完成状況を報告する}

作事が完成すると、再び寄合に報告される。簡単なものとしては 元禄 5 年の『日次記』に、

修理奉行中より被中候二八、方々井垣ノ根継并玉垣ノ柱ノ根継

等、此比大工、二日かつり仕舞之事（12月 8 日条）

とあるように、口頭で伝えられているらしいものもある。また元禄 6 年の『日次記』「貴布祢社修覆之覚」(5月17日条) のなかに、 
一、牛一社打覆之事

一、本社西東)玉垣中ノ柱少根継之事

但、扣根継二メ少斜二根継ヨ可仕、東ノ方八内より $\square$

外より柱可立也

一、北ノ門扣柱武本、西東共ニ根継シテ門傾ヨ叮直事

、南ノ閒傾直シ、柱ノユカミヨ直シ、門ノ扣ヨ可打事

といらように、詳しい内容を記した書面が提出されている場合もある。

また、作事の途中で経過が報告される場合もある。いま述べた元 禄 6 年の貴布被修理でも、ールーラけて「重而修覆可有之分左記」として、

一、同所権殿西ノ方ノ大岩土際上り三尺程上ヨ可切取事

但、此末二ヤ子フキ参候時分、石切呼寄せ検分可申付也

一、同所代動堂西ノ方縁ノツカ木叮取替事、四方ノ縁直ノ事

但、次ノ普請之時、修覆可有之也

(略)

一、同所湯殿ノ事

此修理之義者恨太习張䯏、又八所习替か、猶可請衆評事 などと、修理の完了報告とともに、積从残しとなった個所が報告さ れ、一部は仕様について賀茂別需神社の意向をうかがっている（5月 17 日条)。宝永 6 年の崱布祢における作事でも、賀茂別雷神社の意向 をうかがうため上賀茂に戻った際にほかの修理経過を報告していた ことは先にみた（6月 8 日条）。

さらに新造・修理の前後に社殿で遷宮が行なわれる場合には、修 理方も関与している。例えば、元禄 15 年の藤木社遷宫八の参加（3 月 11 日条) 注38)、宝永 6 年の「二ノ里御社」の権地整備（2月 22 日 条「権地可被相構」）注39)などがある。

\section{3. おわりに}

以上、賀茂別雷神社の造営組織、修理方がどのように営絟活動を 行なっていたかをみた。そして、修理方の行なった活動の流れを次 のように復原した（図 1)。

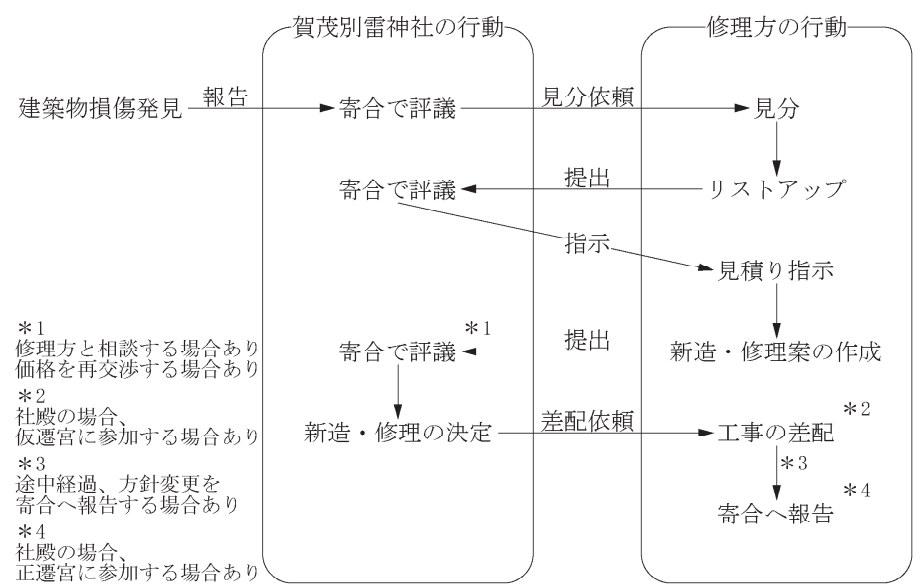

図 1 修理方による営䋨活動の流れ

この活動の流れから、江戸時代の賀茂別雷神社における修理方に よる活動が記録のないものも含め把握できることになる。本稿で扱 った事例はそれぞれ関連のない異なる工事のものである。本論中で も述べたように簡単な工事の埸合や急を要する工事の埸合など復原 した流れの一部は省略されたと考えられるものもある注40)。しかし賀 茂別雷神社では奇合による合議制のもとで運営が行なわれていたこ
とを考えると、復原した活動はす心゙て行なわれることが基本であっ たと考えられる。そのため互いに関連しない個々の事例を網羅-する ことで、省略された部分も含め修理方が行ないうる活動の流れを復 原することが可能となる。個々の事例は、この復原された流れの範 囲内で行なわれることになる。

さらに造営組織である修理力の特徴として、

・祭礼にあたり境内の設営を行なら

・神事である遷宮へ参加する

の2ひが挙げられた。遷宮への参加は神官としてではなく修理方と して参加している。これらの職務は修理方が神社内部の組織である ことによるものである。

な㧍本稿では、修理方と幕府による造営との関係については触れ なかった。正徳度の造営をみると修理方は、

•中井家が事前に行尔う見分につき従う（宝永 6 年 10 月 5 日条）

・役大工の造営参加について賀茂別雷神社から中井家へ願いを めげるにめたり役を一とめる（宝水 7 年 4 月 18 日条）

・普請場」に出頭し、中井家の奉行から摂社と細殿を檜皮草き にするという通達をうけとる（正徳元年 1 月 27 日条） などの役割を担っている注41)。修理方は日常の新造・修理に限らず営 繥活動を行なっていたと考えられる。

注

注 1）川上貢・永井規男「大徳寺の建築工について|『日本建築学会論文報告集』 第 89 号、昭和 38 年 9 月、伏見唯「林家木割書について（1）一林家の由緒一」 『2006 年度日本建築学会関東支部研究報告集』2007 年 2 月、同「林家木割書 について（2）－嘉元期の賀茂別雷神社本殿と木割「賀茂様之三間社」の比 較一」『2006 年度日本建築学会関東支部研究報告集』2007 年 2 月

注 2）前掲「林家木割書について（2）一嘉兀期の賀茂別雷神社本殿と木割「賀 茂様之三間社」の比較一」

注 3）中西大輔・日向進「近世賀茂別雷神社の摂社にみられる木割について।『日 本建築学会近畿支部研究報告集』第 49 号、2009 年 6 月

注 4）整理事業の結果、賀茂別雷神社文書は約 14,000 点あることがわかった。

注 5）『賀茂別雷神社文書目録』京都府教育委員会、平成 15 年 3 月

注 6) 大山喬平監修、石川登志雄・宇野日出生・地主智彦編『上賀茂のもり・ やしろ・まっり』思文閣山版、2006 年 6 月

注 7) 中西大輔 ・ 日向進 |賀茂別雷神社の役大工と営業権について」『日本建築 学会計画系論文集』第 77 巻第 673 号、 2012 年 3 月

注 8) 本稿でいう造営組織は、浜岛一成氏によって「寺社内造営組織」上命名 された組織であり、「寺社内部における工事管理組織」、「寺社側が自前で組 織した営絴組織」のことである（浜島一成『中世日本建築工匠史』相模書房、 平成 18 年 9 月)。

注 9）須磨千頴「中世における賀茂別雷神社氏人の惣について（5)」南山大学 経済学会『南山経済研究』第 9 巻第 3 号、1995 年 2 月

注 10）須磨千穎「中世に抒ける賀茂別需神社氏人の物について（11）| 南山大 学経济学会『南山経济研究』第 12 巻第 1 号、1997 年 6 月

注 11) 建内光儀『上賀茂神社』(学生社、2003 年 12 月)。修理方の人数·職務が「簡 単に」として紹介されている。同書によれば、同書の記載内容は『賀茂別雷 神社由緒略記』によるものであり、「維新直前の職制」を示しているという。 注 12）前揭『賀茂別雷神社文書目録』

注 13) 1 冊の分量は|数百丁から五百丁」(前掲『賀茂別雷神社文書目録』)。

注 14）詳しくは本論および次稿以降でみていくことにするが、修理方は享保 5 年頃までに営繕組織上して新造、修理、資金管理、材料管理の機能をもつ上 うになったと考えられる。なお、本稿で扱う範囲外である元文年間以降の『日 次記』を調查した結果、元文・寛保年間を対象に入れても本稿と同様の結果 が得られると考えられた。造営組織以外の変遷を考えても、寛保年閒以降、 修理方の立場に変化は生じにくいと考えられる。例えば、建築工匠の組織や 造営時の儀式も寛保度の造営以降は先例通りに行なわれている。

注 15）全体の見分には毎回、修理方だけでなく神主、月奉行、六役、正大工が 参加している。ただし、距離のある氏神社境内の建築物け修理方のみが見分 に向っていたり、正人工のみが派遣されていたりする場合もある。 
注 16）またこの場合、修理方が寄合へ報告をあげる場合もあった。曰次記』 から例を举げると、元禄 15 年 10 月 20 日条に、

修理奉行より及披露候八、御園口制札ノ柱根くさり并十楽寺門南/方扉 ひち坪妨、倒有之候由、早々罷可被越候由被申渡者也

というものがある。このほか享保元年 5 月 27 日条にも、貴布祢奥社の旧殿 お小び材木小屋の屋根が損じたことが成就院（寺家の 1 人で貴布袮で活動す る）秥ら修理方に報告されている。

注 17)このような臨時の見分にも修理方のほかに神主や月奉行、六役、正大工 が参加する場合があった。とくに大規模な見分の場合には神主々月奉行、六 役も参加し、さらに正大工が連れて行かれるものと思われる。また、正大工 の办を下見に派遣する例も見られる。例えば宝永 5 年には、貴布袮で行なわ れる修理に向けて正大工を見分に派遣したことが修理方によって寄合で報告 されている (8月 7 日条)。ほかに享保 5 年 6 月 11 日条など。

注 18）見樍りには建築工匠などが行なう見樍りと修理方が行なう見樍りがあ ったようである。建築工匠などは新造・修理にあたり、基本的には与えられ た条件に対に一て見皘り在行なう。一方、修理方媇新造・修理の条件在決定い, それに必要な費用を見積っていると考元られる。修理方が行なら見積りに関 して、㚖保元年に修理方が提出した見積書について賀茂別雷神社から訂正を 求められたという話がある。修理方が初めに提出したものは「舞台小屋」屋 根の坪数を多めに見積もっていた。これについて賀茂別雷神社は屋根の坪数 はあとあともみるものであることを理由に、屋根の坪数认実際の数値を記入 し、別のところで高めの見積もりをするように、という決議が下したのであ った（閈2月2.7日条)。

注 19）その後、再び寄合に修理方も出席のうえ相談が行なわれることもある。 享保 6 年には修理方から橋小屋の「積書」と「絵図」がさしだされたときに「来 ル廿二日、御修理奉行衆二も出座有之而、御相談可然之旨也」といら評決が 下されている (8月 17 日条)。このように、修理方との相談が必要と判断さ れた場合には、次回の奇合まで議題は保留されることがわかる。

また、元禄 10 年に行なわれた全体の見分では修理方が帳面を作成してい るか不明である。すなわち元禄 10 年 2 月 14 日条：

今日社内修覆怱検分有它（略）

社頭番所盢五睤半表替（略）正・権之御垣之内、諸木引取事、掃除講中 八申渡事（略）二鳥井左右井垣六本根継事、右帳面之通、記之

注 20)なお動物とはキツネであり、「不浄等持来候旨」が報告されている。

注 21）全体の見分から新造・修理案が提山されるまでの期間は一定していない。 享保 3 年には、「御修理方より社内舎屋等迄御修復樍艮被差出候事」とあり (3 月 2 日条)、見分から 1 月以上かかっている。享保 4 年には「社頭修復積り帳面 が提出されている(1月 27 日条)。同月の 11 日に見分が行なわれたと寸れば、 2 週間ほど経っている。

なお本文に関連して、修理方から書付を差し出された賀茂別雷神社では「此 通二清書被成可被相椝二極ル」と、さらに清書が行なわれることが決定して いる。元禄 8 年にも修理方による「修覆ノ下帳」が清書のうえ「被窅」こと になっている (7月 27 日条)。

これは修理のリストが奉行所に提出されるものであったためであると考え られる。しかし、必ずしも奉行所に提出されたわけではない。それについて 公儀一破損修理/義一届仕置候而、混物修覆可然存候、内夕競馬前不得 已事、先ツ修覆被致候様二入魂候严、方々修理肝煎ノ御衆御苦労千万, 事也、猶其内公儀八ちらと被钼置可然二極儿（元禄 6 年 5 月 3 日条） などとあるように、競馬会前など奉行所一提山していては時間がかかるると うようなときには先に修理が行なわれていたようである。また、『清茂県主 日記』(IV-A-49) 正德 3 年 7 月 19 日条によ扎ば、「不及届、為一社早速加修 復置穏便它儀可然卜テ」落雷で破損したもの走修理するこ上に決まっている。 もし奉行所から問い合わせがあれば、「少々ノ儀故社山二而加修復」えたと 答えることに決まっている。

注 22）本文引用部分につづき、「其上二而今一応可有沙汰旨之事」とある。建 筑物を大破したもの、小破にとどまっているものにわけて、修理の優先順位 を決定しようとしたことが考えられる。またこのころにはできるだけ早期に 補修を加えるという方針であったようである。同年、貴布祢の「社中ノ家、 殊外破損」の連絡があった。賀茂別雷神社では「大破成不申年州二修理可有 之旨二テ、修理奉行衆江被仰渡畢」といら対応をしている(5月17日条)。

注 $23 ）$ 元禄 10 年にも、惣見分に上って作成された「修覆書付之帳」を 2 日後 に正大工が賀茂別雷神社で受け取っている (2月 16 月条)。正大工に見積り を命じたものと思䄪れる。

注 24）なお、引用文中の|大工」は権棟梁である。また後述するように、この 作事に関して複数の鉎治から見積りが上がっている。入札に近いといえる。 注 25）ほかに、修理方が鉎治に見積りを依頼し、見積り結果を鉎治から受け取 っている例がある (正徳 4 年 11 月 2 日条)。
注 26) 児玉幸多「賀茂別雷神社の集会制度」(『社会経済史学』第 8 巻第 3 号、 昭和 13 年 6 月)。このほか、考若寄合、二手寄合があることも明らかにされ ている。老若寄合は立会寄合の決議について氏人が承・不承を決するために 開いたものである。三手寄合はいわゆる村落の若者仲間と同様のものである。 この三手寄合は若年層の氏人を中心に行なわれる。

注 27) これを恒例寄合あるい梳式日寄合といい、元禄頃からの慣行である。そ れ以前は毎月 2 日、12 日、22 日に行な子れてていたさらに遡って寛文頃に は 7 日または 10 日に 1 度行なわれるもので、開催日は一定していなかった といら。なお、この上うな怕例寄合のほか臨時に開催される臨時寄合があっ たという（前掲「賀茂別雷神社の集会制度」）。

注 28）正徳 4 年に行なわれた評議所の作事でも、修理方が一々質問し、賀茂別 雷神社が決定を下している (正徳 4 年 11 月 27 日条)。

・評議所ノ井、玄関ノ南ノ方二可申付哉ノ事

・同所太鼓置所ノ事、今日者打候八とも、尚御差図可被下候事

・ 同所雪隠建所/事

- 同所ノ張付可被仰付哉/事

これに対して、賀茂別雷神社からは「右之通二可被仰付旨ノ事」「同所ノ南、 巽, 方、宜可有旨，事小、「今迄，少并所，所、上雪㩊卜下，卜両口二又壱所 二可被成候事」「張付師、左兵衛二可被仰付旨ノ事」という決定が伝えられ ている。

注 29）正確には箱棟と品板の間。

注 30）なおここでは、雨が漏る屋根について指板をすることが決定している。

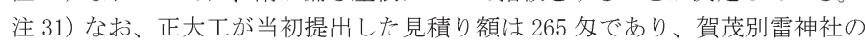
要請を受けて再提出した見積り額は 230 多であった (同 16 日条、18 日条)。

注 32 ) 同様の事例として、元禄 12 年 9 月 17 日条には「社頭雪隠ノ橋破損二付、 修理奉行衆被申付候事」と記されている。

注 33) このほか享保 3 年にも類例がタられる。山森社の燈籠が柱の腐朽により 転倒した。しかし、燈籠自体は無事であった。この報告に対し、賀茂別雷神 社は「修理方より宜可被成候事」という決定を下している（10月７日条）。

注 34）修理方と建築工匠の関係としては本稿で触れている雇用関係のほか、

·建築工匠に詨寸る課役に打ける工数の概算（宝永 6 年 4 月 27 日条）

・正大工からの飯料增額願い的对処（宝永 5 年 8 月 7 日条) などが挙げられる。

注 35）ただし、社殿の新造・修理はあまり行なわれない。これは社殿の修理は 基本的に行なわれながたためである。必要なときには仮遷宮を行なったう え修理が行なわれることもあるが、打覆いで補修することが多い。

注 36) ここで、修理方が賀茂別雷神社の意向をうかがっているのは、賀茂別 雷神社が寄合によって運営されていたためであると考兄られる。修理方は小 寄合に加わっていることからも、賀茂別雷神社の運営に一定の権限をもって いたことがわかる。また修理方には、今回対象とした範囲から外れるものの、 正祢宜なども加わっており（元文 4 年（1739）2 月 19 日条）、身分の低い神 官によッて構成されているわけではない。そのため、害合という合議制によ る運営方針のもとで修理方は活動していたと考えられる。なお、修理方を構 成する神官については修理方の任期とあわせて別稿を予定している。

注37）同 2 日条によれば、

御屋根打丈ケ天井二而留り余程之義二候得共、御队陣者御別条御座有間 敷抔之被存候旨被申也、依之御修理方被招、相談有之、先正大工検分二 被遣、其上二而可有沙汰/旨也

とある。樹木の枝が折れ、屋根が 1 凡四方程破損したという報告が詰番から あったときの評決である。同 3 日条で修理方に正大工を連れて貴布祢へ向か うようにという決定が下っている。ここでは修理方による見分と一緒に修理 が行なわれているこ上がわかる。

注38) ほか比享保 4 年 5 月 9 日・10日条など。

注 39）ほかに享保 4 年 5 月 9 日条「川尾社仮遷宮二付（略）権地被構置」など。 注 40)ここでいう省略には、本文中のように実際省略された場合のほかに、『月 次記』に記録することが省略された場合も考它られる。記録の省略があった かどうかには、日次記』といら史料の性質が関わってくる。釿始めに関する 記述で考えておきたい。釿始めは毎年 1 月 4 日に行なわれている。またこの 日は賀茂御祖神社参詣や謡始めも行な利机ている。しかし、記事が一部省略 されている場合や、日付のほか何も記されていない場合（正德 4 年 1 月 4 日 条など）もある。したがって、『日次記』は一部の記録が省略されるうるも のであるといえる。これには『月次記』が下書きを経て作成されたものであ ること、修理方の日次記というものもあることなど椂从な要因が考えられる。 注 41）さらに努永度造営では、|大破」、|中破」、小破」にわ忊るときに修理 方が関わっている。「(略) 神殿・舎屋等大中小破之儀御修理方并史顕等見分、 社頭へ出頭可有之旨二付直二出頭有之事（略)」(『当社貴布祢御修復神山御 検分一件仮日記』(III-21-15) 安永 2 年 10 月 23 日条)。 